\title{
ПРАВОВІ ОСНОВИ ЗАХИСТУ АВТОРСЬКОГО ПРАВА В МЕРЕЖІ ІНТЕРНЕТ
}

Н. В. Яременко

\author{
Національна медична академія післядипломної освіти імені П. Л. Шупика
}

\section{LEGAL FRAMEWORKS FOR COPYRIGHT PROTECTION ON THE INTERNET}

N. V. Yaremenko

\author{
Shupyk National Medical Academy of Postgraduate Education
}

Вступ. Захист авторського права у світовій правовій традиції розуміють як одну із неодмінних підстав забезпечення фундаментального права людини на інтелектуальну власність, що, в свою чергу, є основоположною для сучасної демократії з дотриманням поваги до прав та гідності людини.

Під захистом авторського права розуміють передбачені законом заходи із їх визнання, припинення ïх порушення, застосування до правопорушників заходів юридичної відповідальності. Захист особистих майнових і немайнових прав суб'єктів авторського права здійснюється в порядку, встановленому цивільним, адміністративним і кримінальним законодавством.

За останні 30 років більш ніж у 20 країнах світу були прийняті нормативно-правові акти стосовно захисту авторського права, в яких закріплені реальні механізми правого регулювання обігу такої інтелектуальної власності.

Мета. Аналіз джерел інформації, законодавчої бази, конвенції і постанови для визначення ефективного захисту авторського права.

Матеріали і методи досліджень. Діалектичний, структурний, порівняльно-правовий методи. Вивчено понад 30 джерел щодо захисту авторського права.

Результати та їх обговорення. Останнім часом все актуальнішою проблемою у вітчизняній науці стає плагіат. Існуючий на сьогодні в Україні правовий механізм притягнення до відповідальності за плагіат є досить неоднозначним. Справа в тому, що з точки зору законодавства прописано достатньо відповідних норм, які дають визначення поняття плагіату, гарантують захист прав авторів, а також встановлюють перелік правопорушень 3 використанням плагіату та заходи відповідальності за нього.

Водночас, незважаючи на досить непогану урегульованість питання відповідальності за плагіат на законодавчому рівні, на практиці, коли постає необхідність захисту порушених прав автора, існують деякі проблеми. Насамперед вони пов'язані 3 пред'явленням доказів. Так, якщо авторське право було порушене при публікації плагіату на веб-сторінці, позивач може подати до суду як додаток до позову лише роздруківку такої сторінки (яка є копією сторінки, а отже має бути засвідчена нотаріально), окрім того, автор не в усіх випадках може відслідкувати час опублікування плагіату в мережі Інтернет, його конкретних авторів (а не лише домен, на якому така сторінка розміщена.

На даному етапі стан законодавчої бази, що стосується захисту авторського права в Україні, потребує значного поліпшення й узгодження 3 міжнародними стандартами шляхом прийняття відповідних змін та доповнень.

Законодавство України про авторське право формально відповідає світовим зразкам, ефективність функціонування яких визнана доктриною та доведена практикою. Незважаючи на наявність ефективного механізму охорони прав автора в Україні, число порушень, як зауважують аналітики із США, зростає. В перспективі це може завдати шкоди не лише майновим інтересам окремих авторів чи їх правонаступників, а й сукупному показнику інтелектуального та науково-технічного потенціалу України - закономірно, що автор не буде зацікавлений у творчості в тій країні, де ніхто не зможе надати адекватних гарантій захисту результатів його творчості. 
На думку багатьох авторів, найдієвішим способом захисту авторських прав є компенсація моральної шкоди. Якщо був виявлений факт плагіату на чию-небудь роботу, то автору достатньо написати позовну заяву про відшкодування моральної шкоди. Також потрібно посилювати дисциплінарну відповідальність за плагіат: оголошувати попередження за плагіат в курсових, дипломних роботах, наукових статтях, дисертаціях; при повторному застосуванні плагіату оголошувати догану. Виявлений у тексті дисертації плагіат також повинен бути достатньою умовою для позбавлення людини наукового ступеня кандидата або доктора наук.

Для ефективного захисту авторського права потрібно: ввести норми, які б передбачали відпо- відну компенсацію суб'єктам авторського права за завдану їм шкоду; розробити процедури, що забезпечують виявлення та доказ випадків незаконного використання об'єктів авторського права; посилити відповідальність за незаконне використання об'єктів авторського права; забезпечити ефективну реалізацію санкцій і процедур тощо.

Висновки. Необхідна подальша робота з систематизації авторського права, розробки підзаконних актів, відповідних національних стандартів, чіткого визначення термінів, понять та категорій. Також слід акцентувати увагу на принципі судового захисту. 